\title{
PEMANFAATAN BUAH PALA (Myristica fragrans) UNTUK MENGATASI KETENGIKAN (RANCIDITY) PADA MINYAK KELAPA YANG DIBUAT DENGAN CARA TRADISIONAL
}

\author{
Suraidah, Noni Febriani, Shabri Putra Wirman \\ Mahasiswa Jurusan Fisika, Email:suraidahafnaa@gmail.com \\ Dosen Jurusan Fisika, Email: nonifebriani@umri.ac.id \\ Dosen Jurusan Fisika, Email: shabri_pw@yahoo.com \\ Universitas Muhammadiyah Riau \\ Jl. KH. Ahmad Dahlan No.88, Sukajadi Pekanbaru-28124 \\ Telp. (0761) 35008, 20497 Fax (0761) 36912
}

\begin{abstract}
ABSTRAK
Salah satu pemanfaatan buah kelapa adalah dengan mengolahnya menjadi minyak goreng. Penelitian ini bertujuan untuk mengetahui sejauh mana buah pala dapat mencegah proses ketengikan minyak kelapa yang dibuat dengan cara tradisional. Parameter yang diukur adalah uji massa jenis, viskositas, dan $\mathrm{pH}$ yang dilakukan di Laboratorium Fisika Terpadu, uji angka peroksida dilakukan di Laboratorium Kimia Terpadu Fakultas MIPA dan Kesehatan Universitas Muhammadiyah Riau, uji bau, dan uji warna yang dinilai oleh sepuluh orang panelis. Hasil penelitian menunjukkan bahwa minyak kelapa $50 \mathrm{ml}$ dengan penambahan 2 gram bubuk biji pala yang berfungsi sebagai antioksidan dapat mencegah proses ketengikan minyak kelapa yang dibuat dengan cara tradisional. Hal ini berdasarkan hasil analisis parameter yang digunakan.
\end{abstract}

Kata kunci: Minyak kelapa, ketengikan, antioksidan, buah pala

\section{PENDAHULUAN}

Tanaman kelapa (Cocos nucifera) merupakan salah satu tanaman monokotil. Tanaman ini tumbuh di sepanjang pesisir pantai khususnya dan dataran tinggi. Batang pohon kelapa umumnya berdiri tegak dan tidak bercabang. Daunnya berpelepah, panjangnya dapat mencapai 3-4 meter lebih dengan siripsirip lidi yang menopang tiap helainya. Buahnya terbungkus dengan serabut dan batok yang cukup kuat sehingga untuk memperoleh buah kelapa harus dikuliti terlebih dahulu. Tanaman kelapa banyak memiliki manfaat salah satunya adalah buahnya bisa menjadi bahan baku minyak goreng. Buah kelapa bisa dibuat minyak goreng secara tradisional dengan menggunakan peralatan yang sederhana oleh masyarakat pemilik kebun kelapa [1].

Sejauh ini kelapa hanya dimanfaatkan sebatas kebutuhan pangan sehari-hari oleh masyarakat dan belum diolah lebih lanjut. Salah satu pemanfaatan buah kelapa yang paling potensial adalah dengan mengolahnya menjadi minyak goreng. Hanya saja pengolahan tersebut mengalami kendala karena minyak hasil olahan cepat tengik. Hal ini menyebabkan kurangnya daya tarik masyarakat untuk mengolah dan menggunakan minyak dari buah kelapa [1].

Minyak goreng dari kelapa adalah minyak goreng yang paling sehat dan aman, kandungan asam lemaknya mencapai $92 \%$. Disamping itu, minyak kelapa juga tidak menghasilkan radikal bebas yang bersifat toksin (racun) dan karsinogenik (penyebab kanker). Buah kelapa bisa dibuat minyak goreng, terutama daging kelapa yang sudah tua merupakan sumber minyak nabati kandungan minyaknya mencapai $35 \%$. Karena kualitas minyak goreng dari kelapa bagus untuk kesehatan, sehingga harganya lebih mahal dari minyak kelapa sawit $[1,2]$.

Minyak goreng dari kelapa yang dibuat dengan cara tradisional dapat mengalami ketengikan. Hal ini dapat terjadi disebabkan selama proses pengolahan menggunakan suhu yang tinggi dan juga akibat campuran dari produk lain. Selain menimbulkan bau yang tidak sedap juga dapat menurunkan nilai gizi karena 
rusaknya vitamin. Sehingga minyak kelapa yang dibuat dengan cara tradisional tidak bisa disimpan pada waktu yang lama [3].

Ketengikan pada minyak kelapa dapat diatasi dengan usaha menambahkan bahan yang mengandung antioksidan. Antioksidan adalah zat yang dapat menunda, memperlambat dan mencegah terjadinya reaksi antioksidasi radikal bebas. Antioksidan dapat menghambat proses ketengikan karena antioksidan lebih reaktif dari oksigen. Molekul aktif dari antioksidan adalah menggagalkan terbentuknya peroksida dengan mengikat oksigen [3].

Berdasarkan hasil penelitian yang dilakukan Osy Yostia Utami (2011) bahwa, komponen minyak atsiri pada daun sirih berfungsi sebagai antioksidan. Sebanyak 87 gram minyak kelapa dengan konsentrasi $3 \%$ antioksidan dapat mencegah atau menghambat ketengikan pada minyak kelapa, sehingga bertahan sampai hari ke 20 [4].

Berdasarkan uraian diatas, maka penelitian ini dilakukan dengan memanfaatkan biji pala yang berfungsi sebagai antioksidan untuk mengatasi ketengikan minyak kelapa yang dibuat dengan cara tradisional.

\section{METODOLOGI PENELITIAN}

\section{Waktu dan Tempat Penelitian}

Penelitian ini dilakukan di Laboratorim Fisika Terpadu dan Laboratorium Kimia Terpadu Fakultas MIPA dan Kesehatan Universitas Muhammdiyah Riau. Pembuatan minyak dilakukan di Desa Pembatang, Kecamatan Pangean, Kabupaten Kuantan Singingi, Riau. Penelitian berlangsung mulai bulan Maret dan selesai pada bulan Mei 2013.

\section{Alat dan Bahan}

Alat

Alat yang digunakan pada penelitian ini adalah neraca digital, viskometer Oswald, $\mathrm{pH}$ meter, gelas ukur, pipet tetes, botol sampel, blender, neraca kasar, dan erlemeyer $250 \mathrm{ml}$ bertutup basah. Alat bantu untuk pembuatan minyak kelapa adalah parut kelapa, baskom, wajan, pengaduk dan saringan.

\section{Bahan}

Minyak kelapa 2,25 liter, bubuk biji pala 90 gram. Bahan untuk uji peroksida $\left(\mathrm{Na}_{2} \mathrm{~S}_{2} \mathrm{O}_{4}\right.$, $\mathrm{CH}_{3} \mathrm{COOH}, \mathrm{CHC}_{13}$, larutan $\mathrm{KI}$ (Kalium Iodida), air suling larutan pati $1 \%$, dan alkohol).

\section{Proses Pembuatan Minyak Kelap}

Proses pembuatan minyak kelapa dilakukan dengan cara tradisional melalui proses pemanasan. Daging buah kelapa diparut dan diperas dengan menghasilkan santan murni 18 $\mathrm{kg}$ kemudian ditambah air 5 liter. Setelah itu dilakukan pemanasan selama 6 jam dengan menghasilkan minyak dan blondo (padatan). Minyak dipisahkan dari blondo dengan cara penyaringan. Setelah penyaringan dilakukan pendinginan selama 1 jam pada udara terbuka.

\section{Desain Penelitian}

Perlakuan penelitian yang digunakan adalah penetapan bahan antioksidan (bubuk pala) yang digunakan selama pengambilan data, yaitu:

- A : Minyak kontrol (murni) $50 \mathrm{ml}$

- B : Minyak $50 \mathrm{ml}+$ bubuk pala $1 \mathrm{gr}$

- C : Minyak $50 \mathrm{ml}+$ bubuk pala 2 gr

- D : Minyak $50 \mathrm{ml}+$ bubuk pala $3 \mathrm{gr}$

- E : Minyak $50 \mathrm{ml}+$ bubuk pala $4 \mathrm{gr}$

\section{Metode Penelitian}

\section{Massa Jenis}

Pengukuran massa jenis minyak kelapa dilakukan dengan mengukur massa dari minyak kelapa dibagi dengan volume minyak kelapa. Minyak kelapa dimasukkan ke dalam gelas ukur $50 \mathrm{ml}$ sebanyak $25 \mathrm{ml}$ dengan massa gelas kosong 2,255 oz. Kemudian minyak ditimbang dengan menggunakan neraca digital. Setelah diketahui massa minyak maka dapat diketahui massa jenis dengan Persaman 2.1. Metode ini dilakukan 3 kali pengulangan pada setiap sampel.

\section{Viskositas}

Pengukuran viskositas dilakukan dengan menggunakan viskometer Oswald. Sampel diambil $50 \mathrm{ml}$ dan dimasukkan kedalam viskometer ostwald, sampel akan terhisap oleh 
pompa sampai di atas tanda a, kemudian sampel dibiarkan mengalir ke bawah, waktu yang diperlukan dari a ke b ditulis dan dihitung menggunakan stopwatch. Kemudian dianalisis dengan Persamaan 2.2. Pengambilan data ini dilakukan 3 kali pengulangan pada setiap sampel.

\section{Uji Bau}

Uji bau dilakukan secara subjektif dengan menggunakan responden dari 10 orang panelis. Dalam uji ini minyak yang telah disimpan dari hari 1 sampai hari ke 56 disajikan kepada para panelis (guru-guru SDN 003 Kota Garo). Untuk uji bau skala yang digunakan yaitu (1) bau tengik, (2) biasa, dan (3) bau rempah.

\section{Uji Warna}

Uji warna dilakukan secara visual untuk mengetahui warna minyak kelapa yang dihasilkan dengan olahan tradisional. Penentuan warna dilakukan dengan cara mengamati setiap sampel minyak kelapa. Minyak disajikan kepada 10 orang panelis. Untuk uji warna skala yang digunakan yaitu (1) sangat kuning, (2) kuning, dan (3) jernih.

\section{pH}

Alat yang digunakan untuk pengambilan data minyak kelapa pada penelitian ini adalah $\mathrm{pH}$ meter. Celupkan alat ( $\mathrm{pH}$ meter) ke dalam sampel, setelah dicapai kestabilan pengukuran, nilai sampel akan diketahui dengan membaca nilai yang langsung ditunjukkan oleh alat tersebut. Metode ini dilakukan 3 kali pengulangan pada setiap sampel.

\section{Angka Peroksida}

Ditimbang secara tepat 5,0 gram minyak kelapa ke dalam erlermeyer $250 \mathrm{ml}$ yang bertutup basah. Kemudian ditambahkan campuran larutan asetat, alkohol, dan kloroform (20:20:55) dan dikocok hingga larut. Lalu ditambahkan $1 \mathrm{ml}$ larutan KI jenuh dibiarkan di tempat gelap selama 1 jam sambil sekali-kali larutan digoyang. Kemudian ditambahkan $50 \mathrm{ml}$ air suling. Campuran tersebut dititrasi dengan larutan do sulfat $0,02 \mathrm{~N}$, titrasi harus dilakukan secara tepat sampai warna kuning hampir hilang (kuning muda). Lemudian ditambahkan Larutan Indikator kanji $0,5 \mathrm{ml}$ dan titrasi dilanjutkan. Erlermeyer digoyang secara cepat sampai mendekati titik akhir yaitu warna biru gelap menghilang. Metode ini dilakukan berdasarkan SNI 01-3394-1998 dengan 2 kali pengulangan pada setiap sampel.

\section{Teknik Analisis Data}

\section{Analisis Tabel dan grafik}

Dalam analisis ini dideskripsikan dengan tabel, yaitu massa jenis ( $\rho$ ), kekentalan (viskositas), $\mathrm{pH}$, dan angka peroksida.

\section{HASIL DAN PEMBAHASAN}

\section{Hasil}

\section{Massa Jenis}

Massa jenis merupakan sifat fisis yang biasanya digunakan untuk menyatakan tingkat kemurnian minyak. Proses oksidasi pada minyak kelapa dapat mempengaruhi besar kecilnya massa jenis. Peningkatan massa jenis juga disebabkan oleh penambahan bubuk biji pala. Hasil analisis massa jenis minyak kelapa setelah penambahan bubuk biji pala dapat dilihat pada Gambar 1.

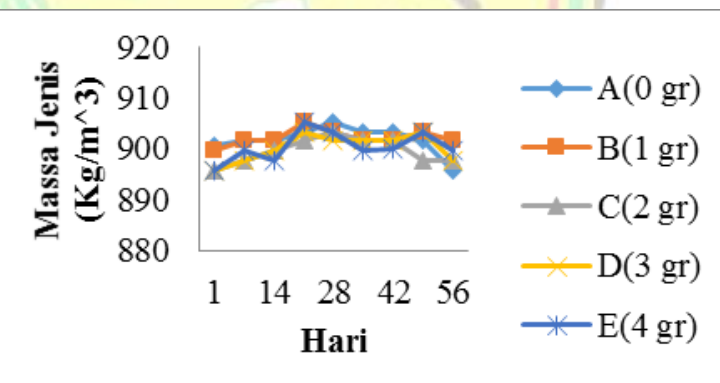

Pada sampel B, C, D, dan E memiliki nilai massa jenis lebih tinggi dibandingkan dengan sampel A dengan selisih nilai 1,89 gram - 5,66 gram. Hal ini disebabkan telah dilakukan penambahan bubuk biji pala. Karena dalam biji pala mengandung minyak atsiri 7-14\%. Minyak atsiri ini akan mempengaruhi nilai massa jenis pada minyak kelapa. Semakin banyak penambahan bubuk biji pala, maka akan meningkatkan nilai massa jenis. Semakin tinggi nilai massa jenis, artinya minyak semakin tidak murni. Dan semakin rendah nilai massa jenis 
minyak semakin murni. Rendahnya nilai massa jenis juga disebabkan oleh pemanasan sehingga ikatan antar molekulnya berkurang $[8,10]$.

Pada hari ke 49 semua sampel mengalami kenaikan lagi, kecuali sampel $\mathrm{C}$ mengalami penurunan. Sampel C juga memiliki nilai yang stabil dibandingkan dengan sampel yang lain. Hal ini menunjukkan pada konsentarsi 2 gram bubuk biji pala pada volume minyak kelapa 50 $\mathrm{ml}$ dapat mengatasi proses oksidasi. Proses oksidasi akan meningkatkan massa jenis minyak kelapa [10].

\section{Viskositas}

Viskositas merupakan salah satu parameter yang diujikan untuk mengetahui kualitas minyak kelapa. Viskositas dapat digunakan sebagai salah satu indikator dalam penentuan kerusakan minyak. Terbentuknya nilai viskositas disebabkan oleh adanya pembentukan senyawa polimer dalam minyak. Polimer merupakan senyawa yang terbentuk di dalam minyak akibat pemanasan terus menerus pada suhu tinggi [15]. Hasil analisis nilai viskositas minyak kelapa dapat dilihat pada Gambar 2.

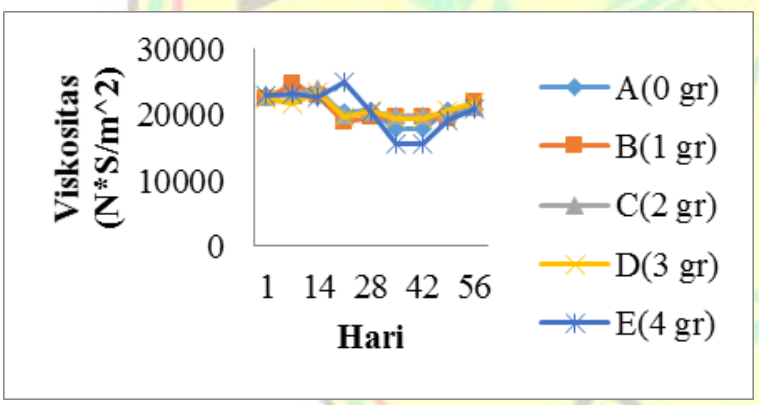

Selain itu terbentuknya nilai viskositas disebabkan karena adanya proses oksidasi yang terjadi pada minyak. Dimana viskositas minyak kelapa akan meningkat dengan bertambahnya molekul asam lemak. Tinggi rendahnya nilai viskositas juga disebabkan oleh suhu ruang pada waktu pengambilan data dan suhu pada waktu pengolahan minyak. Pada waktu suhu tinggi kekentalan minyak bisa berkurang dan pada waktu suhu rendah kekentalan minyak bisa bertambah [12]. Sehingga semua sampel pada penelitian ini selalu mengalami kenaikan dan penurunan.

\section{Uji Bau}

Uji bau merupakan salah satu parameter untuk mengetahui kualitas minyak kelapa yang diuji oleh 10 orang panelis dengan menggunakan indera penciuman. Proses oksidasi oleh oksigen terhadap asam lemak tak jenuh akan menimbulkan bau tidak enak pada minyak kelapa yang diolah dengan cara tradisional [12]. Hasil analisis uji bau dapat dilihat pada Gambar 3.

Berdasarkan Gambar 3 sampel A memiliki kecenderungan menurun dimulai dari hari ke 14 hingga hari ke 56. Hal ini membuktikan pada sampel A, semakin lama waktu penyimpanan minyak berbau tengik. Bau tengik disebabkan oleh proses oksidasi oleh oksigen terhadap minyak. Hal ini sesuai dengan penelitian yang dilakukan oleh Eni Fajrin (2012) bahwa, proses oksidasi berlangsung bila terjadi kontak antara sejumlah oksigen dengan minyak. Terjadinya reaksi oksidasi akan mengakibatkan bau tengik pada minyak [12].

Pada sampel $\mathrm{B}$ dan $\mathrm{C}$, juga memiliki kecenderungan menurun. Hasil analisis ini menunjukkan bahwa, pada konsentrasi 1-2 gram bubuk biji pala pada volume minyak kelapa 50 $\mathrm{ml}$ bau tengik pada minyak kelapa dapat dihilangkan. Namun pada sampel D dan E, memiliki kecenderungan naik dimulai dari hari ke 7 hingga hari ke 56. Sampel D dan E yang tercium oleh panelis minyak kelapa berbau rempah (pala). Hal demikian disebabkan terlalu banyak penambahan bubuk biji pala.

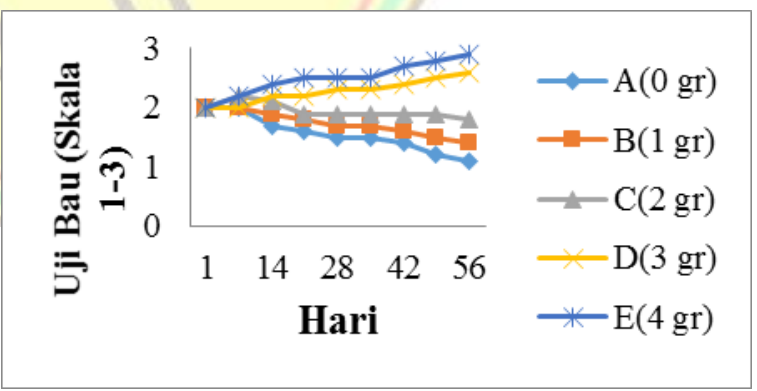

Secara fisis parameter bau dapat menjelaskan pengaruh dari penambahan bubuk biji pala. Dimana dengan adanya penambahan bubuk biji pala, bau tengik minyak kelapa yang teroksidasi dan proses pengolahan dengan 
menggunakan suhu yang tinggi dapat dihilangkan.

\section{Uji Warna}

Uji warna merupakan salah satu uji parameter secara visual oleh responden dari 10 orang panelis. Proses oksidasi dan waktu pengolahan menggunakan suhu yang tinggi akan mempengaruhi warna alamiah pada minyak yang diolah dengan cara tradisional [16]. Perubahan warna alamiah minyak kelapa juga bisa disebabkan oleh penambahan dari bubuk biji pala. Hasil analisis uji warna dapat dilihat pada Gambar 4.4.

Berdasarkan Gambar 4.4 sampel A memiliki nilai tetap (3) dari hari 1 hingga hari ke 56. Hal ini menunjukkan pada sampel A minyak kelapa berwarna jernih. Warna jernih merupakan warna alamiah dari minyak kelapa [16].

Pada sampel B, memiliki kecenderungan menurun dari hari ke 7 hingga hari ke 14 . Setelah melewati hari ke 14 nilainya tetap hingga hari ke 56. Hal ini menunjukkan sampel B berwana kuning. Warna kuning ini disebabkan oleh penambahan bubuk biji pala dan senyawa karetenoid yang larut dalam minyak. Senyawa karetenoid adalah pigmen warna yang tidak stabil dengan panas [12].

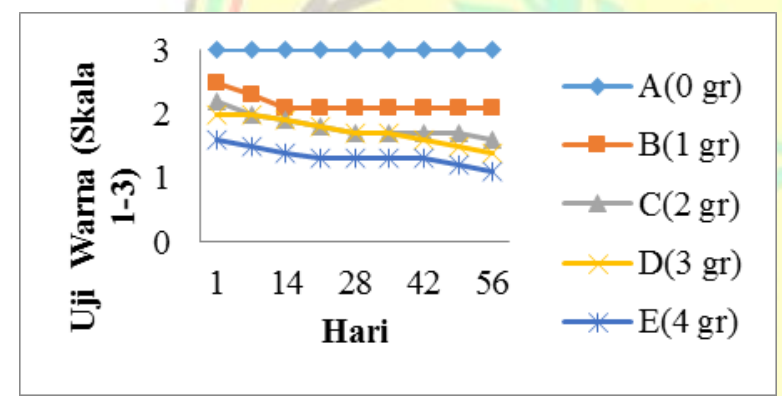

Namun pada sampel C, D, dan E memiliki kecenderungan menurun dari hari ke 7 hingga hari ke 56. Hal ini menunjukkan pada sampel C warna minyak kelapa masih berwarna kuning, sampel D dan E berwarna sangat kuning. Warna sangat kuning ini disebabkan terlalu banyak mengandung bubuk biji pala. Selain itu minyak kelapa juga mengandung pigmen karetenoid atau zat warna alamiah yang dapat membentuk warna kuning pada saat dilakukan pemanasan [12].
Nilai $\mathrm{pH}$ suatu sampel dapat menunjukkan derajat keasaman suatu larutan. $\mathrm{pH} \quad 7$ menunjukkan keadaan netral atau normal, $\mathrm{pH}$ di bawah 7 menunjukkan keadaan asam, dan $\mathrm{pH}$ di atas 7 menunjukkan keadaan basa. Minyak kelapa yang diolah dengan pemanasan suhu tinggi dalam waktu yang lama akan meningkatkan jumlah asam lemak bebas dalam minyak [9]. Hasil analisis pH minyak kelapa dapat dilihat pada Gambar 4.5.

Berdasarkan Gambar 4.5 semua sampel memiliki kecenderungan naik pada hari ke 7 , kemudian pada hari ke 14 memiliki kecenderungan menurun. Hasil analisis ini menunjukkan nilai $\mathrm{pH}$ masih dibawah angka 7 (netral). Hal ini menunjukkan pH minyak kelapa tanpa antioksidan dengan minyak kelapa penambahan antioksidan masih bersifat asam. Dari analisis ini dapat dilihat tidak ada pengaruh antioksidan terhadap minyak kelapa yang teroksidasi.

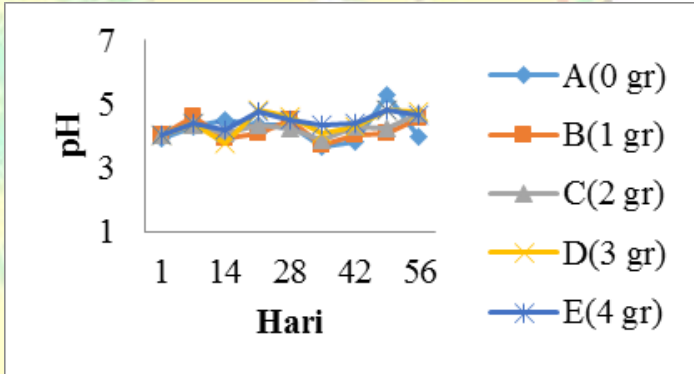

Pada hari ke 35, semua sampel memiliki kecenderungan menurun. Namun pada hari ke 49 sampel A mengalami kenaikan yang segnifikan. Hal ini disebabkan sampel A tidak dilakukan penambahan antioksidan. Namun semua sampel ini memiliki nilai $\mathrm{pH}$ masih di bawah angka 7 (netral). Pada penelitian ini, uji pH yang dilakukan memiliki nilai yang tidak stabil dan masih menunjukkan keadaan asam. Keasaman ini disebabkan oleh pemanasan dengan suhu tinggi dalam waktu yang lama yang meningkatkan asam lemak bebas dalam minyak [9].

\section{Angka Peroksida}

Penentuan angka peroksida merupakan salah satu jenis parameter uji ketengikan yang digunakan untuk mengetahui tingkat kerusakan 
minyak. Adanya angka peroksida disebabkan oleh proses oksidasi asam lemak tak jenuh dalam minyak dan dipercepat oleh adanya cahaya, suasana asam dan kelembaban udara [3]. Hasil analisis angka peroksida dapat dilihat pada Gambar .6.

Berdasarkan Gambar 4.6 sampel A memiliki nilai angka peroksida paling tinggi, artinya sampel A tingkat kerusakan minyak sangat tinggi. Hal ini menunjukkan pada penyimpanan yang lama, minyak kelapa tanpa antioksidan kerusakannya sangat tinggi. Tingginya angka peroksida disebabkan oleh proses oksidasi antara oksigen dengan asam lemak tak jenuh [3].

Pada sampel $\mathrm{B}$ dan $\mathrm{C}$ angka peroksida mengalami penurunan. Artinya tingkat kerusakan minyak menurun. Hal ini menunjukkan bahwa penambahan bubuk biji pala 1-2 gram pada volume minyak kelapa $50 \mathrm{ml}$ lebih efektif mengurangi kenaikan angka peroksida pada minyak kelapa yang teroksidasi. Menurut penelitian yang dilakukan oleh Fahrurizal Laitupa dan Hismi Susane (2009) bahwa, angka peroksida pada minyak kelapa yang teroksidasi dapat diatasi dengan penambahan antioksidan [17].

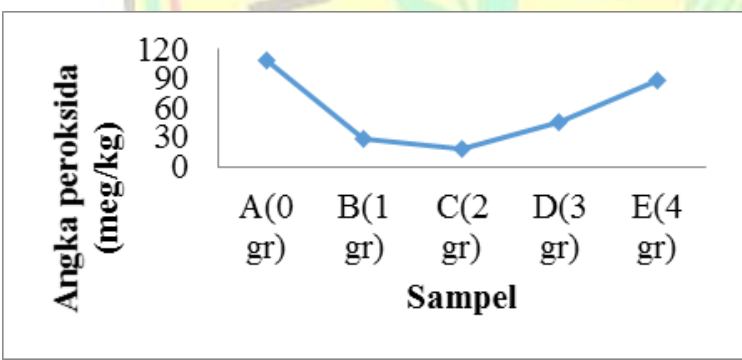

Pada sampel D dan E angka peroksida mengalami kenaikan mencapai 88,64 meg/kg. Hal ini disebabkan terlalu banyak penambahan bubuk biji pala. Dengan demikian dapat disimpulkan bahwa semakin banyak penambahan bubuk biji pala angka peroksida semakin tinggi.

Berdasarkan uji parameter, angka peroksida berhubungan nyata dengan massa jenis, viskositas, dan $\mathrm{pH}$. Hal ini ditunjukkan kestabilan nilai massa jenis, viskositas, dan $\mathrm{pH}$ terdapat pada sampel $\mathrm{C}$ dan nilai angka peroksida paling rendah terdapat pada sampel C.
Dengan analisis uji parameter, angka peroksida paling tinggi hingga mencapai 100 maka minyak kelapa semakin tengik dan bersifat racun sehingga tidak bisa dikonsumsi [17].

\section{KESIMPULAN DAN SARAN}

\section{Kesimpulan}

Kesimpulan yang dapat diambil dari penelitian ini adalah:

1. Pada parameter massa jenis dan viskositas minyak kelapa yang mempunyai nilai stabil terdapat pada sampel C.

2. Sampel $\mathrm{C}$ dengan komposisi 2 gram bubuk biji pala, dapat mencegah proses ketengikan pada minyak kelapa.

3. Pada volume minyak kelapa $50 \mathrm{ml}$ dengan penambahan 2 gram bubuk biji pala lebih efektif mengurangi angka peroksida.

\section{Saran}

Saran yang dapat diambil dari penelitian ini adalah:

1. Untuk penelitian berikutnya dapat dilakukan uji kimia dan biologi yang berguna untuk mengetahui stabilitas dan kualitas minyak kelapa.

2. Dapat dilakukan uji organoleptik berdasarkan tingkat kesukaan panelis.

3. Untuk mencegah proses ketengikan minyak kelapa yang dibuat dengan cara tradisional dapat menggunakan bahan antioksidan yang lain.

\section{DAFTAR PUSTAKA}

Sunnara, R., dan I. Khastrifah. 2009. Sukses Besar dengan Kelapa. Banten. Talenta Pustaka Indonesia.

Ismadi, Janu. 2009. Ensiklopedi Buah untuk Kesehatan. Banten. Kenanga Pustaka. Indonesia.

Siswati, N. Dyah. 2008. Pemanfaatan Antioksidan Alami Flavonol untuk Mencegah Proses Ketengikan Minyak Kelapa. Jurnal Kimia FTI UPN "Veteran" Hal 1-4. 
Utami, O. Yosita. 2011. Komponen Minyak Atsiri Daun Sirh (Piper tetle. L) dan Potensinya dalam Mencegah Ketengikan Minyak Kelapa. Skripsi. Fakultas Matematika Ilmu Pengetahuan Alam Institut Pertanian Bogor.

Wicaksono, B. Setyo. 2007. Budi Daya Tanaman Obat. Jakarta. CV. Karya Mandiri Nusantara.

Nohong. 2008. Pemanfaatan Limbah Debu Tanur Pembakaran Laterit Nikel (Raw Gas) sebagai Adsorben untuk Meningkatkan Mutu Minyak Kelapa. Staf Pengajar pada Jurusan Kimia FMIPA UNHALU.

Susilowati, Eko. 2010. Toga Tanaman Obat Keluarga. Jakarta. CV. Sinar Cemerlang Abadi.

Rahadian, D. Dita. 2009. Pengaruh Ekstrak Biji Pala (Myristica fragrans) Dosis 7,5 $M g / 25$ grbb terhadap Waktu Induksi Tidur dan Lama Waktu Tidur Mencit Balb/C yang Diinduksi Thiopental. Tesis. Fakultas Kedokteran Universitas Diponegoro Semarang.

Marsel, R. Paranta. 2013. Pengaruh Penambahan Minyak Atsiri Daun Sirih Hutan (Piper aduncum L.) terhadap Minyak Goreng yang Teroksidasi secara Termal. Jurnal Kimia Terapan Vol. 1 Hal 55-59.

Sutiah, dan F. K. Firdausi. 2008. Studi Kualitas Minyak Goreng dengan

Parameter Viskositas dan Indeks Bias. Jurnal FMIPA Vol. 11 No. 2 Hal. 53-58.

Hari, B. Sapta. 2010. Mengenal Benda dan
Sifatnya. Jakarta. CV. Rama Edukasi Tama.

Fajrin, Eni. 2012. Penggunaan Enzim Bromelin pada Pembuatan Minyak Kelapa (Cocos Nucifera) Secara Enzimatis. Skripsi. Fakultas Pertanian Universitas Hasanuddin Makasar.

Utami, L. Indrati. 2008. Pengambilan Minyak Kelapa dengan Proses Fermentasi Menggunakan Scharomyces Cerevicerae Amobil. Jurnal Teknik Kimia FTI-OPNV Hal 5-13.

Hidayati, Nur. 2009. Bilangan Iodium Minyak Kelapa Hasil Olahan Tradisional dan Hasil Olahan dengan Penambahan Buah Nanas Mentah. Jurnal Kimia dan Teknologi ISSN 0216-163 X Hal 7-11.

Febriansyah, Reza. 2007. Mempelajari Pengaruh Penggunaan Berulang dan Aplikasi Adsorben terhadap Kualitas Minyak dan Tingkat Penyerapan Minyak pada Kacang Salut. Skripsi. Fakultas Teknologi Pertanian Institut Pertanian Bogor.

Anwar, R. Wiradhika. 2012. Studi Pengaruh Suhu dan Jenis Bahan Pangan terhadap Stabilitas Minyak Kelapa Selama Proses Penggorengan. Skripsi. Fakultas Pertanian Universitas Hasanuddin Makasar.

Laitupa, F., dan S. Hismi. 2009. Pemanfaatan Eugenol dari Minyak Cengkeh untuk Mengatasi Ranciditas pada Minyak Kelapa. Jurnal Teknik Kimia. Hal 8. 